\title{
虚血性脳血管障害超急性期における核医学脳機能画像の 意義一SPECTおよびPETについて
}

\author{
下瀬川恵久 \\ ‘秋田県立脳血管研究センター放射線医学研究部
}

\begin{abstract}
Key words : PET（ポジトロン断層撮影装置），SPECT (単光子断層撮影装置)，MRI (磁気 共鳴断層装置), 脳酸素消費量, 灌流一拡散画像
\end{abstract}

(脳卒中 $24: 536$ - 541, 2002)

虚血性脳血管障害では, 虚血巣の有無, 範囲, 重症 度を迅速に評価することが重要である．核医学脳機能 検查は, Single Photon Emission Computed Tomography（SPECT）による脳血流測定の利便性の向上に伴 い, 過去 10 年以上にわたり臨床の現場において虚血性 脳血管障害の脳循環の評価に活用されてきた。本稿で は, 脳梗塞急性期の脳血流 SPECT の有用性を再確認 するとともに, 超急性期の Positron Emission Tomography (PET) 測定による虚血巣の代謝を含めた評 価についての我々の検討結果を報告し，さらに Magnetic Resonance Imaging (MRI) 機能画像之 PET 画像 を対比することによって，急性期の脳機能評価方法の 今後の展望について述べる.

脳血流 SPECT 測定は, ${ }^{99 m} \mathrm{Tc}$ 製剂の開発により, 発 症数時間以内の脳梗塞急性期での利用が可能になっ た。このため, 1990 年代から発症 6 時間以内の脳血流 SPECT 所見と長期臨床予後との対比や血栓溶解療法 施行例での測定結果が報告されるようになった．Hanson らによる発症 6 時間以内の SPECTでの脳血流低 下と 3 カ月後の Barthel Indexによる予後評価との相 関やや，Baird らやInfeldらによる Streptokinase 投与 前後の脳血流 SPECT 所見の変化々臨床予後の関係 ${ }^{233}$ は，急性期の SPECT 測定が長期臨床予後の予測や血 栓溶解療法の脳血流モニタリングに有効であることを 示した.一方，これらの報告では一定の放射能值以下 の虚血域を容積的に算出する手法が行われていたた め, 解析に時間を要し, 救急医療の現場での脳血流 SPECT 利用は汎用性にをしかった。 そこで, 虚血の程 度を迅速かつ客観的に判定して治療へ結びつけるため に, 虚血巣の放射能值を健常部分の放射能值で簡便に
標準化する半定量的な評価が行われるようになり，形 態学的あるいは臨床予後的䚻結と対比することによっ て, 虚血閾值が設定された. Giubilei らは, 発症 6 時間 以内の technietium-99m hexamethylpropyleneamine oxime ( $\left.{ }^{9{ }^{2} \mathrm{~m}} \mathrm{Tc}-\mathrm{HMPAO}\right)$ を用いた脳血流 SPECT 測定の 結果, 患側対健側比で 0.4 以下の虚血巣を有し, かつ入 院時の Canadian Neurological Scale (CNS) が 6.5 以下 の症例では, 発症 1 力月後の予後が不良であったと報 告している ${ }^{4}$. Shimosegawa らは, 同じく発症 6 時間 以内に ${ }^{2 \%} \mathrm{Tc}-\mathrm{HMPAO}$ を用いた脳血流 SPECT 測定で の虚血域と follow-up CT 上の梗塞域および非梗塞域 とを対比して, 梗塞巣が出現する虚血閾値は患側対健 側比で 0.4 以下の領域であるとした5. このような簡 便な虚血闎値の測定が臨床的に最も寄与するのは, 脳 梗塞急性期に血栓溶解療法の適応を考虑する場合であ る. 療法後に重篤な出血性梗塞が生じる閾值は, Ueda らが対小脳比で 0.35 以下, Ezura らも対健側比で 0.35 以下であり ${ }^{677}$ ，雨者は一致している。また，再開通に より梗塞の発生を免れる闘値は, Sasaki らが対小脳比 で $0.55 \sim 0.75$, 対健側比で $0.65 \sim 0.85$ としており ${ }^{87}$, Ezura らは対健側比で $0.35 \sim 0.70$ としている”. 以上 の報告を図 1 にまとめる. ${ }^{99 \mathrm{~m} T \mathrm{~T}-H M P A O ~ S P E C T て ゙ ~}$ は, 定量的な PET 测定と比べて正常小脳の血流量が 高く算出されるため，一般的に対小脳比は対健側比よ りも低く算出されることや，直線化補正を行わないと 比が過大評価されることなどを考虑すると, 対小脳比 と対健側比による虚血閾値はよく一致している。した がって，これらの簡便かつ半定量的評価方法は，施設 の差異による影響が少ない, 安定した指標であるとい える。 


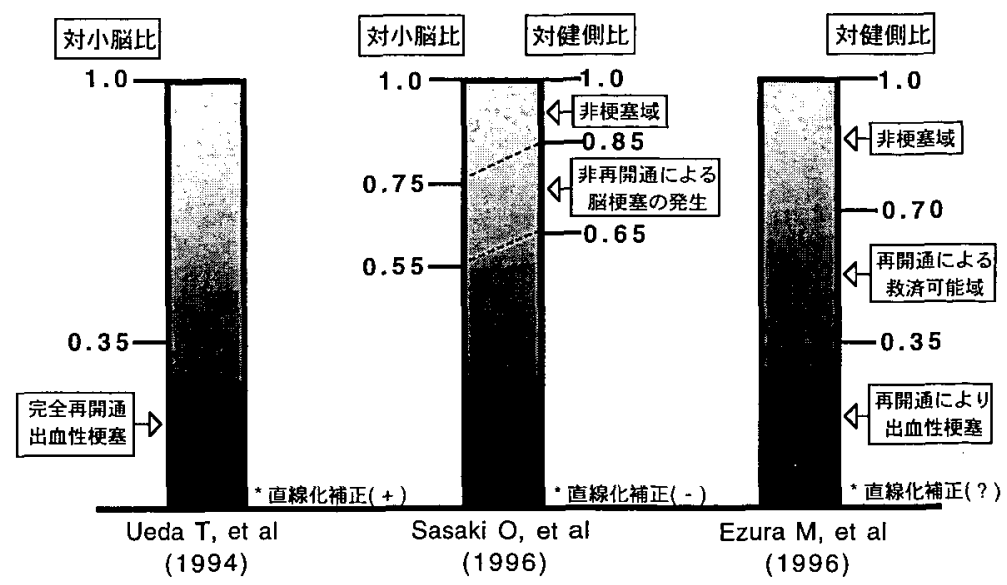

図1 各文献の報告に基づいた SPECT 測定による血栓溶解璙法前の残存脳血流量と 䡒法後の形態学的予後. Ueda T万 (文献 6 参照), Sasaki O 万 (文献 8), Ezura $\mathrm{M}$ ら（文献 7) の報告より抜粋. 対小脳比, 対健側比で 0.35 以下の著明な虚血域で は，急性期の血栓溶解療法後に再開通が得られた場合でも重篤な出血性梗塞を合併 する場合があり，適忍を考虑する必要がある。

一方, 脳梗塞の脳血流 SPECT 所見では, 発症 6 時間 以内の急性期に打いても血流が変動し，10\%程度の頻 度で局所的な血流上昇が観察される の局所脳循環調節の障害により血管麻㽻が生じた部位 に対して, 閉塞血管の自然再開通や側副血行路の発達 により血流が供給され，異常な高血流を示すものと考 えられる。このような部位では，脳品流測定のみで組 織障害の程度を知ることは不可能であり, 組織代謝の 情報を得ることが重要と思われる．現在，代謝のパラ メーターはPET のみで測定可能であるが，定量的評 価のためには入力関数測定のための動脈確保や脳血液 量補正のための $\mathrm{C}^{15} \mathrm{O}$ 測定が必要で, 最低でも検査に約 90 分を要し，緊急検查には適さない。そこで，我々は 動脈採血を行わず, $\mathrm{H}_{2}{ }_{2}^{15} \mathrm{O}$ 静注㧍よび15 $\mathrm{O}_{2}$ 吸入後の放射 能值のみを画像化し，虚血域の放射能值を健常域の放 射能值で標準化して，それぞれ定性的脳血流量捛よび 脳酸素消費量として急性期の脳組織障害の評価を試み た。この方法では, 検查全体に要する時閭は約 30 分で ある。一側性脳底部主幹動脈閉塞症例での検討では， $\mathrm{H}_{2}^{15} \mathrm{O}$ および ${ }^{15} \mathrm{O}_{2}$ 画像の患側対健側比は，それぞれ PET 定量画像の同比と良好な正の相関を示した（定量的脳 血流量対 $\mathrm{H}_{2}{ }^{15} \mathrm{O} ; \mathrm{y}=0.28+0.76 \mathrm{x}, \mathrm{r}=0.98$, 定量的脳酸 素消費量対 $\left.{ }^{15} \mathrm{O}_{2} ; \mathrm{y}=0.28+0.76 \mathrm{x}, \mathrm{r}=0.94\right)$ ．また， $\mathrm{H}_{2}{ }^{15}$ $\mathrm{O}$ 扔よび ${ }^{15} \mathrm{O}_{2}$ 画像から算出した ${ }^{15} \mathrm{O}_{2} / \mathrm{H}_{2}{ }^{15} \mathrm{O}$ の患側対健
側比は，定量的脳酸素摄取率の同比と良好な正の相関 関倸を示した $(\mathrm{y}=0.28+0.76 \mathrm{x}, \mathrm{r}=0.94)$. 以上から, $\mathrm{H}_{2}^{15} \mathrm{O}$ 抢よび占 $\mathrm{O}_{2}$ 画像を用いて放射能值を患側刘健側 比で評価する方法は, PET 定量測定法に比べて簡便に 脳梗塞急性期の脳循環代謝情報を得ることができ， misery perfusion の領域も検出可能であることが明ら かとなった。

さらに我々はこの定性的な PET 検査方法を用い て, 現在 MRI 機能画像で tissue at risk 領域として評 価されている灌流画像と搪散強調画像との mismatch 領域の病態を比較し検討した。この mismatch 領域に 関しては, 脳梗塞症例の約 20\% で経過観察中に梗塞巣 が掂大することが知られている一方, 拡散強調画像の 信号正常化に伴って mismatch 領域が消失することも 報告されて扮り，病態生理学的な意義は未だ不明であ る. 我々は, 一側性脳底部主幹動脈閉塞症例で, 定性 的 PET 検査㧍よびMRI 機能画像検查を発症 6 時間 以内に施行し, 各画像を発症 3 日後の $\mathrm{MRI}_{2}$ 強調画 像に対して registration を行った後, 両者を対比した。 入院時のMRI 拡散強調画像で信号上昇を示し, 3 日後 の MRI で完全梗塞巣へ移行した部位を虚血中心域, 灌 流画像と拡散強調画像との mismatch 領域の中で 3 日 後の MRI で梗塞巣が拡大した領域を梗塞拡大域, mismatch 領域の中で梗塞巣が発生しなかった領域を灌 
流異常域として，この 3 領域に関して関心領域を設定 した. その結果を図 2 に示す．患側対健側比による定 性的脳血流量および脳酸素消費量の平均は，それぞれ 虚血中心域で $0.24 \pm 0.11$ および $0.30 \pm 0.13$, 梗塞拡大域 で $0.42 \pm 0.07$ および $0.53 \pm 0.07$, 灌流異常域で $0.57 \pm$ 0.10 および $0.76 \pm 0.10$ であり，灌流晎常域に比して梗 塞掋大域では有意に低下していた $(p=0.05, p=0.001)$. 特に梗塞拡大域の定性的脳酸素消費量は, 発症 6 時間 以内で既に健倒の $53 \%$ まで低下しており，灌流異常域 の定性的脳酸素消費量の低下と明確に区別が可能で あった，定性的脳酸素椇取率は，虚血中心域，梗塞搪

A

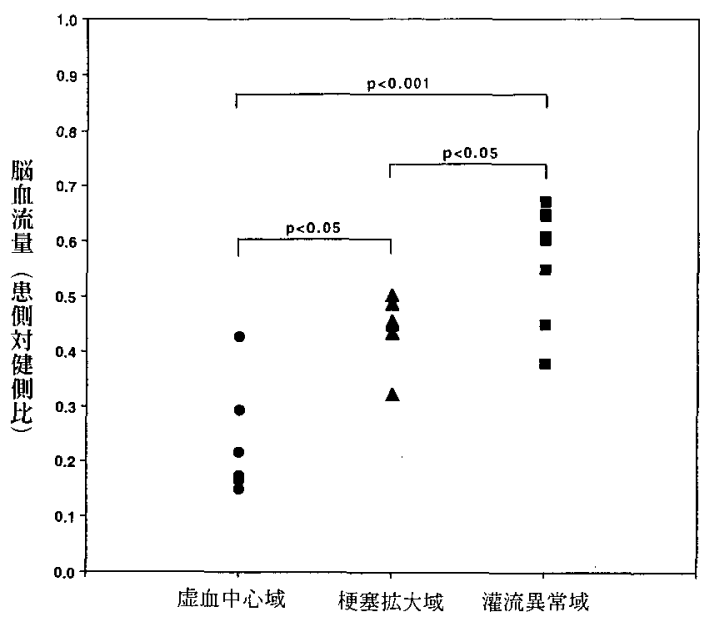

C

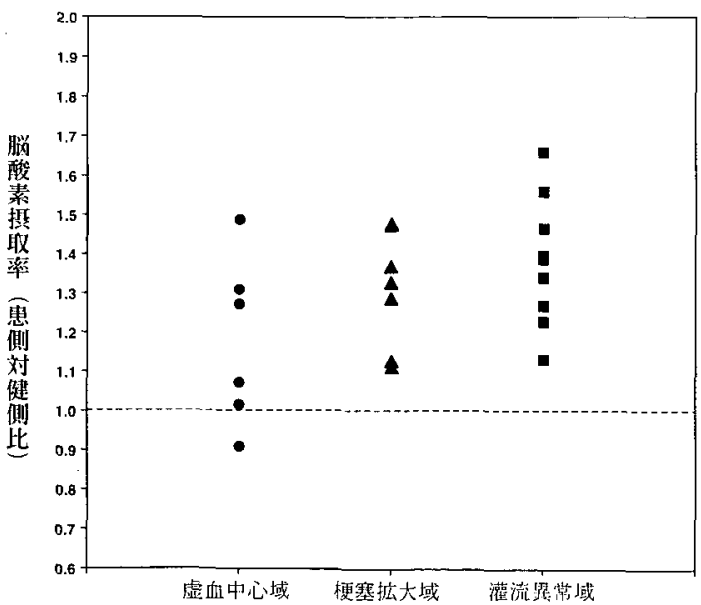

大域，灌流異常域でそれぞれ $1.18 \pm 0.22,1.31 \pm 0.15$, $1.38 \pm 0.17$ であり，3 領域ともに健側に比して上昇して misery perfusionの状態を示していた. 特に梗塞搪大 域抢よび灌流異常域では, 健側の $30 \%$ 以上の有意な上 昇を認めた $(\mathrm{p}<0.01)$ ，代表的な症例を図 3 に示寸。ま た，梗塞拡大域と灌流異常域の間では，拡散強調画像 上の信号変化や拡散係数值の変化に有意差を認めず, 急性期の拡散画像から梗塞搪大域を予測することは不 可能であった。

以上の結果より, 脳梗塞発症から 3 日以内に梗塞巣 が拡大する領域では, 発症直後から酸素代謝が低下し

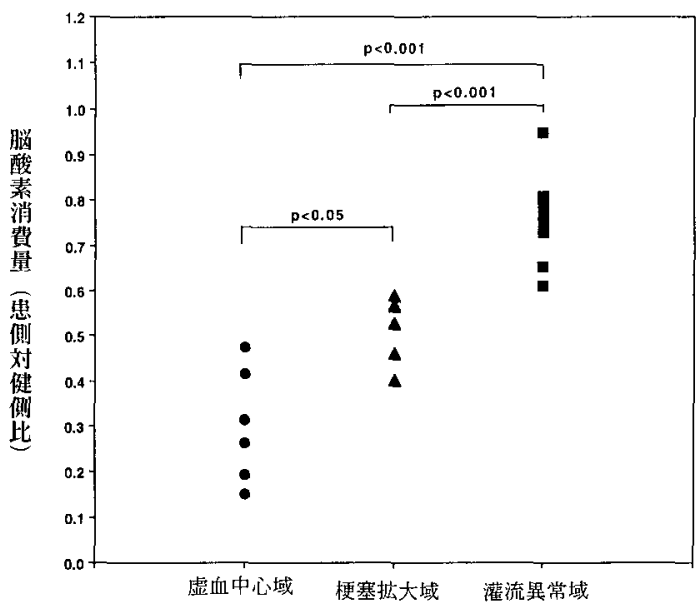

图 2 贫性的PET を用いて測定した発症 6 時間以内 の MRI 機能画像の脳循環代謝. MRI 灌流一拡散画 像_たの虚血中心域，梗塞拡大域，灌流買常域の脳血 流量 $(\mathrm{A})$ ，脳酸素消費量 $(\mathrm{B})$ ，および脳酸素掑取率 (C). 灌流異常域に比して梗塞掘大域では, 発症 6 時 間以内の時点で既に平均で健側の $53 \%$ まで酸素代 謝が低下している。また，いずれの領域も発症 6 時 間以内には脳酸素掑取率が上昇しており， misery perfusionの状態を示している。 


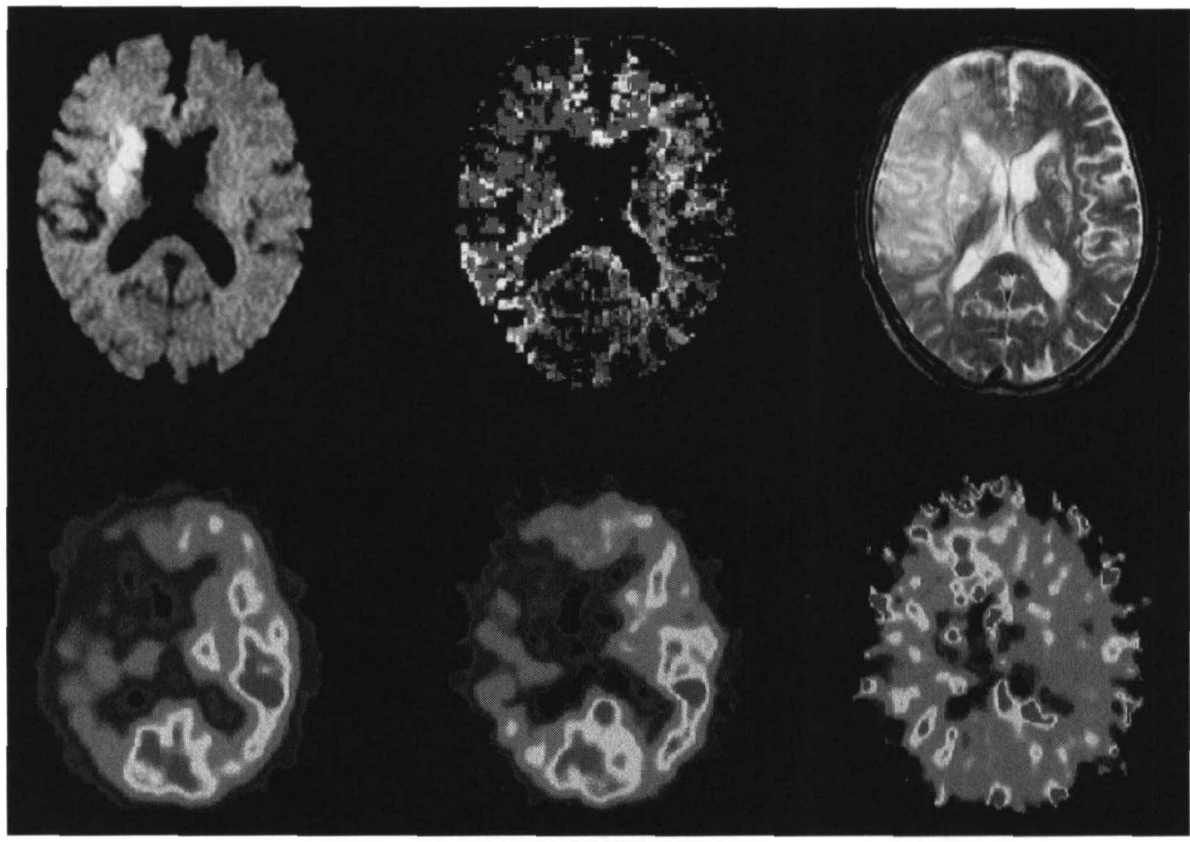

図 3 右内頸動脈閉塞症例. 発症 4 時間後の MRI 拡散強調画像（上段左）では，右基底核を中 心とした著明な信号上昇域を認める，平均循環時間による MRI 灌流画像（上段中）では，右 内頸動脈領域の広範な灌流障害を認める。発症 3 日後の MRI T 2 強調画像 (上段右) では, 入 院時の拡散強調画像の信号上昇域よりも拡大した領域で梗塞巣が形成されている. 発症 3 時 間後に施行した定性的 PET 検査では, 拡散強調画像の信号上昇域での著明な脳血流量(下段 左）および脳酸素消費量（下段中）の低下のみならず，梗塞拡大域でも両者は低下している. 脳酸素摂取率（下段右）は，灌流異常域に一致して広範に上昇している.

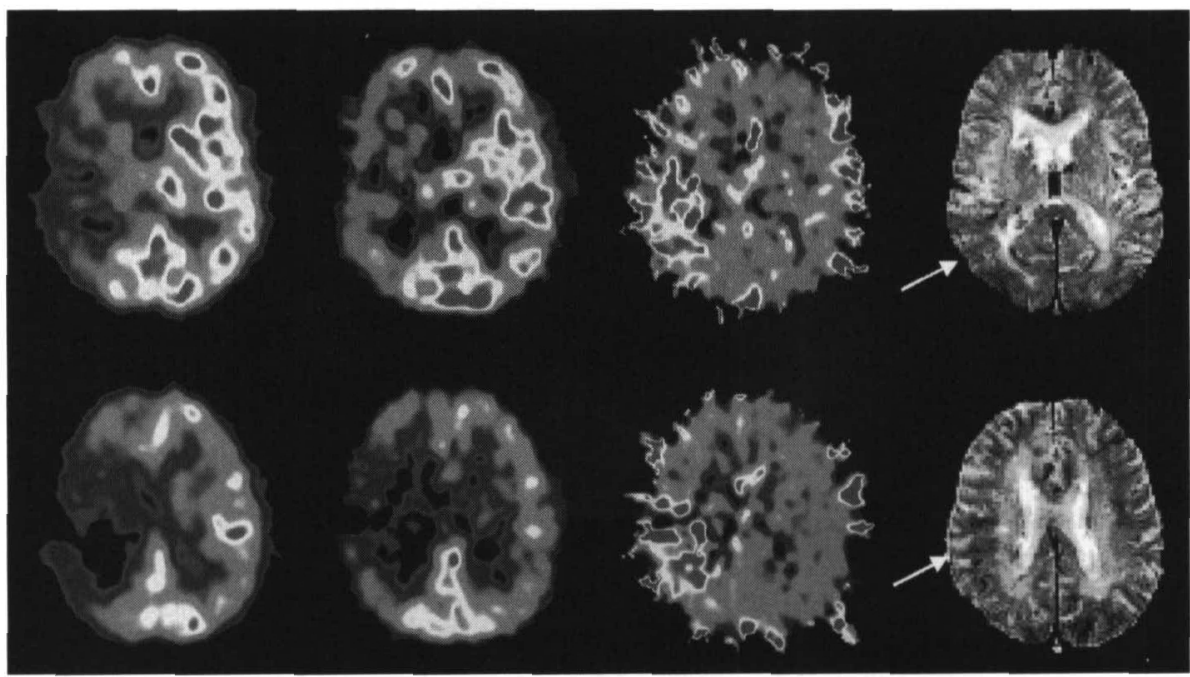

図4 右中大脳動脈起始部閉塞症例. 左列から順に, 発症 110 分後の定性的 PET 検査による脑 血流量, 細酸素消費量, 脳酸素摂取率, および発症 80 分後の BOLD-T ${ }_{2}^{*}$ 強調画像. 右中大脸 動脈領域の脳血流量は広範に低下しており，特に後枝領域で著明である。脳酸素消費量も同 領域で低下しているが, 脑血流量の低下に比べ軽度であり, その結果として細酸素摂取率は 著明に上昇している. BOLD-T2 ${ }_{2}^{*}$ 強調画像では, 脳酸素捸取率の上昇域に一致して信号が低下 している（白矢印）。 
ていることが明らかとなった。同時期に測定した拡散 画像ではこの領域に変化がないことから，発症 6 時間 以内の時点に扔いて, 梗塞拡大域の酸素代謝の低下は あるものの，イオンポンプの障害による水分子の搪散 低下には至っていないことが示唆される。この領域で は, 発症 6 時間以上を経過すると，虚血間值が上昇し， 水分子の搪散障害から不可逆性脳組織障害へと移行す るものと思われ，急性期の再灌流療法や脳保護剂投与 などにより梗塞巣拡大を防止することができる領域と いえる，以上のように，脳梗塞による組織障害を最小 限に留めるためには, 組織代謝の情報を得ることが重 要であり, 定性的 PET 测定は, 緊急時において簡便に この情報を提供することが可能である.

一方, MRI では脳侐流量に相当する情報は得られる が, 組織代謝の情報は単独では得られない。しかし, misery perfusionのような循環と代謝の不均衡を知る ことは叮能である．酸化へモグロビンは反磁性体であ る一方, 脱酸化へモグロビンは常磁性体であるため, 両者の血液中での相対量に依存した $\mathrm{T}_{2}$ およよ゙ $\mathrm{T}_{2}{ }^{*}$ 緩 和洔間の短縮が生ずる. 脳血流量の低下に比して脳酸 絜消費量の低下が少ない misery perfusion 場合には, 酸化へモグロビンに比べて脱酸化へモグロビンの量が 相対的に増加しているため, $\mathrm{T}_{2}{ }^{*}$ 强調画像の信号值が 低下する。Tamura らは一側性の中大脳動脈閉塞症例 に対して，発症 4 時間以内に施行した Blood Oxygen Level Dependent (BOLD) 法による MRI T ${ }_{2}^{*}$ 強調画像 の信号変化を検討した結果, 患㑡半球の $\mathrm{T}_{2}{ }^{*}$ 值の低下 を報告しており，misery perfusionの領域は MRIでも 検出可能であるとしている9．我々の検討でも，発症 6 時間以内に施行した定性的 PETに执ける脳酸素摄取 率の上昇部位と BOLD-T ${ }_{2}{ }^{*}$ 強調画像の信号低下域はよ く一致していた(図 4).このことは, misery perfusion のような脳循環代謝の不均衡部位を簡便に検出すると いう点において MRI は有力な力法となり得ることを 示しており,さらにMRIによる酸素代謝画像作成へ発 展する可能性も秘めている。 今後は一過性脳虚血発作 や慢性期の閉塞性脳血管障害での検討を重ねることに よって，その有用性が確認され，かつ定量的な評価方 法が確立されることにより，MRI 機能画像は虚血巣の 病態に関して核医学的検查方法と同等の情報をもたら すものと思われる。

虚血性脳血管障害の超急性期における画像診断で は，最短の時間で最大の情報を得る必要がある，核医 学検查では急性期におけるSPECTの利便性が向上し
た結果，脳血流測定については姫富な臨休実績に基づ いた虚血闇值が簡便かつ安定した数値として算出可能 である.PETについても，定性的手法を用いれば，代 謝を含めた複数のパラメーターの迅速な評価が可能で あり，核医学固有の情報をもたらし得る。一方，高磁 場 MRIの普及により, MRI 機能画像も沉用化されつ つあるが，その信号変化を PET と対比することに よって, 画像の示す病態生理学的背景を明らかになる ものと考える。

\section{文献}

1) Hanson SK, Grotta JC, Rhoades H, et al : Value of single-photon emission-computed tomography in acute stroke therapeutic trials. Stroke $24: 1322-$ 1329, 1993

2) Baird AE, Donnan GA, Austin MC, et al : Reperfusion after thromboly tic therapy in ischemic stroke measured by single-photon emission computed tomography. Stroke 25:79-85, 1994

3) Infeld B, Davis SM, Donnan GA, et al : Streptokinase increases luxury perfusion after stroke. Stroke 27 : 1524-1529, 1996

4) Giubilei F, Lenzi GL, Di Piero V, et al : Predictive value of brain perfusion single-photon emission computed tomography in acute ischemic stroke. Stroke 21:895-900, 1990

5) Shimosegawa E, Hatazawa J, Inugami $\mathrm{A}$, et al : Cerebral infarction within six hours of onset : prediction of completed infarction with technetium99m-HMPAO SPECT. J Nucl Med : 1097-1103, 1994

6) Ueda $T$, Hatakeyama $T$, Kumon $Y$, et al : Evaluation of risk of hemorrhagic transformation in local intra-arterial thrombolysis in acute ischemic stroke by initial SPECT. Stroke $25: 298-303$. 1994

7) Ezura M, Takahashi A, Yoshimoto $T$ : Evaluation of regional cerebral blood flow using single photon emission tomography for the selection of patients for local fibrinolytic therapy of acute cerebral embolism. Neurosurg Rev 19: 231-236, 1996

8) Sasaki O. Takeuchi S, Koizuimi T, et al : Complete recanalization via fibrinolytic therapy can reduce the number of ischemic territories that progress to infarction. Am J Neuroradiol $17: 1661-1668$. 1996

9) Tamura H, Hatazawa J, Toyoshima H, et al : Detection of deoxygenation-related signal change in acute ischemic stroke patients by $T_{2}^{*}-$ weighted 


\title{
Abstract \\ Imaging of hyperacute cerebral infarction by means of single photon emission computed tomography and positron emission tomography
}

\author{
Eku Shimosegawa, M.D, Ph.D. \\ Department of Radiology and Nuclear Medicine, Akita Research \\ Institute of Brain and Blood-Vessels
}

The usefulness of Cerebral Blood Flow ( $\mathrm{CBF}$ ) measurement by single photon emission computed tomography (SPECT) has been verified in patients with hyperacute stage of cerebral infarction, especially when a thrombolytic therapy is considered. Measuring residual CBF before thrombolysis is very important because patients with more than $40 \%$ decrease in CBF compared with the contralateral normal brain is at high risk of crucial hemorrhage after recanalization. Positron emission tomography (PET) can provide metabolic information of the ischemic brain in addition to the severity of CBF deterioration, and would be a powerful diagnostic tool if the measurement becomes feasible in emergency. We investigated qualitative PET measurement that took only half an hour for the examination, and demonstrated that qualitative PET could detect areas with misery perfusion in the affected cerebral hemisphere. Comparing the qualitative PET imaging with the functional magnetic resonance imaging (MRI) obtained within 6 hours after ischemic attack, we delineated that areas with perfusion-diffusion mismatch on MRI contained the area with decrease of oxygen metabolism where progressed to the irreversible brain damage without initial decrease of water diffusion. Qualitative PET measurement has the possibility to explicate the background of signal change of functional MRI that performed in the hyperacute stage of cerebral infarction.

Key words : PET, SPECT, MRI, $\mathrm{CMRO}_{2}$, PWI-DWI mismatch 